\title{
The Contingent Effect of Justice on Foci Commitment for Teachers of Public Universities: An Empirical Test of the Moderating Role of Trust
}

\author{
Shueh-Chin Ting ${ }^{1, *}$ \\ ${ }^{1}$ Department of Education, National University of Tainan, Taiwan \\ *Corresponding author: Department of Education, National University of Tainan, 33 Sec. 2, \\ Shu-Lin St., Tainan 70005, Taiwan. E-mail: tingsc@ms49.hinet.net
}

Received: July 5, 2013

doi:10.5296/ije.v5i3.3963
Accepted: August 7, 2013 Published: August 15, 2013

URL: http://dx.doi.org/10.5296/ije.v5i3.3963

\begin{abstract}
In public university setting, whether trust in supervisor would attenuate the relationship justice and commitment is not certain. In addition, past commitment research focused on organizational commitment, but neglected the foci of commitment. This study investigated the moderating role of trust in supervisor in the relation of distributive justice, procedural justice, and interactional justice with foci commitment (commitment to school, commitment to supervisor, and commitment to colleagues). It was expected that the relationships between three types of justice and foci commitment were weaker for those with high trust in their supervisor. This study uses teachers in public universities as the research sample, collects data by questionnaire survey, and analyzes data through hierarchical moderator regression. This study finds that whether trust in supervisor has the attenuating effect for the influence of justice on commitment depends on the type of justice and commitment. Trust in supervisor can attenuate all relationships between three types of justice and commitment to supervisor. However, regarding commitment to colleagues, trust in supervisor can only attenuate the effect of distributive justice on it.
\end{abstract}

Keywords: foci commitment; justice; public university; teacher; trust 


\section{Introduction}

Commitment is of substantial interest in organizational research. This is grounded in the belief that employee commitment can predict organizational and individual outcomes, such as, employee turnover, performance, and intention to stay in or leave an organization (Razak, Darmawan and Keeves, 2010). In educational settings, teacher commitment is also very important to the school because teacher commitment can increase teachers' job performance and teacher quality (Tsui and Cheng, 1999).

Historically, commitment research focused on commitment to organization. The conventional commitment view is that employee attachment involves the relative strength of an individual's identification with and involvement in a particular organization, not a person (Yang, Wu, Chang and Chien, 2011). Recent research has begun to recognize that commitment has different foci; that is the targets to which employees are committed (Cohen, 2003; Wasti and Onder, 2009). It is of value to discriminate among foci commitments because teachers' views, values and behavior may vary, depending on which commitments are operating (Singh and Billingsley, 1998), such as commitment to school, students, teaching work, and profession (Razak et al., 2010).

In addition, even though there have been research of exploring commitment to other targets or foci (e.g., Redman and Snape, 2005; Vandenberghe and Bentein, 2009), most of the prior studies only examined important organizational outcome variables such as intention to quit, satisfaction and work behavior (Bentein, Stinglhamber and Vandenberghe, 2002; Clugston, Howell and Dorfman, 2000; Veurink and Fischer, 2011). The current study addresses this gap by examining the antecedents of three different foci: the organization, supervisor and colleagues.

Regarding the antecedents of commitment, the empirical findings of the relationship between justice and commitment were not consistent. Iverson and Roy (1994) suggested that reinforcing an employee's perception of justice can increase attitudinal commitment and then increase behavioral commitment. Magner and Welker (1994) indicated that procedural justice improves commitment, but distributive justice does not. In contrary, Mo (2002) found that procedural justice and distributive justice are both critical predictors of commitment. These inconsistent findings may be due to the target of commitment is not clearly defined and the moderator is neglected.

In addition, Nowakowski and Conlon (2005) suggested that further studies of the justice-outcome relations are needed to focus on the moderators. We consider that trust may be a moderating variable in the relationship of justice and commitment, but there are few related studies.

In summary, if the commitment target is considered, are the moderating effects of trust different? Specifically, by using school teachers as research subjects, this study wishes to extend commitment theory by probing into the moderating effects of trust on relationships between justice and foci commitment (commitment to school, commitment to supervisor, and commitment to colleagues). 


\section{Research Variables and Hypothesis Development}

This section reviews and describes the literature on justice, commitment, and trust, and proposes the research hypothesis.

\subsection{Justice}

Justice refers to the employees' subjective cognition of fairness regarding resource distribution, decision making, and interactions within the organization. Novelli, Kirkman, and Shapiro (1995) suggested that creating a climate of justice is a prerequisite for effectively transforming an organization. In general, justice involves distributive justice, procedural justice, and interactional justice. In three types of justice, distributive justice was developed first. The concept of distributive justice emphasizes results and contents of distribution and refers to the level of fairness of resource distribution and employees' reactions to the distribution results (Folger and Greenberg, 1985). Procedural justice stresses fairness of decisions' procedures and processes (Folger and Greenberg, 1985). Interactional justice focuses on fairness of interpersonal interactions and communications (Bies and Moag, 1986).

According to the equity theory of Adams (1965), employees compare their input-outcome ratio with others to determine their cognition of justice or injustice. If they feel injustice, they may react as follows: twist theirs or others' input or outcomes, lead others to change their input or outcome by certain behaviors, change their own input or outcome, select other reference points, or quit the job. Thus, when teachers perceive injustice, there may be negative attitudes or behaviors.

This study defines school justice as teachers' subjective cognition of fairness for internal resource distribution, decision making, and personal interactions in schools. It includes three aspects: distributive justice, procedural justice, and interactional justice. Distributive justice is related to teachers' perceptions of distribution of school resources, such as work load, responsibility, and reward distribution. Procedural justice is related to teachers' perception of school decision-making processes and procedures. Interactional justice is related to teachers' perception of communication and respect.

\subsection{Commitment}

Most previous research on commitment addressed employees' commitment to their organization, which is called organizational commitment, and in particular, belongs to affective commitment which is defined as an emotional attachment to, identification with and involvement in the organization (Hartog and Belschak, 2007).

However, studies of commitment have shifted to multiple dimensions and to multiple targets (foci) (Becker and Kernan, 2003; Bentein et al., 2002; Clugston et al., 2000; Hartog and Belschak, 2007; Jiang and Cheng, 2003). A number of theorists and researchers had differentiated foci and bases of commitment (Becker, Billings, Eveleth and Gilbert, 1996). Bases (dimensions) of commitment are the motives engendering employees' attachment (O'Reilly and Chatman, 1986). The commitment of multiple dimensions generally refers to affective commitment, continuance commitment, and normative commitment. On the other 
hand, foci of commitment are the individuals and groups to whom an employee is attached to (Reichers, 1985). Becker (1992) used 1305 employees in 30 U.S. companies to conduct an empirical research, and found that compared with multiple dimensions, multiple targets of commitment could more effectively explain employees' organizational behaviors. Similarly, the findings of Gregersen (1993) and Becker and Billings (1993) also supported the importance of commitment of multiple targets. Recent research showed that individuals form different strengths of attachment to multiple foci, such as their organization, supervisor, or work-group (Clugston et al., 2000).

In summary, if we exclusively focus on the organization when exploring commitment, the implication of the research will be too narrow. Therefore, this study explores commitment to organization, supervisor, and colleagues, and defines commitment as the employee's psychological identification with organizational objectives and values, a willingness to follow supervisors, and interact with colleagues.

\subsection{Trust}

Trust is a kind of psychological state (Rousseau, Sitkin, Burt and Camerer, 1998), regarding individuals' positive expectations toward the intentions and behaviors of other members in the organization (Shockley-Zalabak, Ellis and Winograd, 2000), and the employees' overall perception of the reliability of the organization (Tan and Tan, 2000).

Blau (1964) noted two types of interpersonal interactions: social exchange and economic exchange. Social exchange means that two parties aim for future returns rather than immediate profits. Economic exchange refers to equal immediate benefits exchange of two parties. The former is based on trust, the latter based on a calculated basis. Hence, when two parties trust each other, even if no immediate returns, devotion is possible.

In the school setting, the exchange between school and teachers is hard to adopt economic orientation. For school, we believe that social exchange is more encouraged than economic exchange. In social exchange, trust is an important variable. In this study, we view trust as an overall variable and it means teachers' trust in their school. Teachers trust in their school, when they believe their efforts will be mentally and substantially returned in the future.

\subsection{Hypothesis Development}

The moderating effects should be considered in the studies of justice (Nowakowski and Conlon, 2005). If a causal relationship between two variables changes, being due to a third variable, the third variable is a moderator. Next, this study will explain the moderation of trust on the relationship between justice and commitment.

Logically, one's response to an action taken by another party will be a direct function of the action. However, the same action could be differently interpreted and reacted, depending upon the level of trust that one has in the other party (Dirks and Ferrin, 2001). Hence, trust may affect the extent of the action's salience. Without trust, partner transactions will be direct and short-term (McDonald, 1981) and a partner's action will be severely monitored. Under high levels of trust, one is more likely to respond favorably to a partner's action than under low 
levels of trust (Dirks and Ferrin, 2001). Trust affects one's interpretation of another's action. Employees with high trust will tend to attribute unfair treatment to unfortunate circumstances rather than to the deliberate intention of the employer (Robinson, 1996). Therefore, employees perceive unfair treatment is less severe and less intentional when they have high trust (van den Bos, Wilke and Lind, 1998).

Robinson (1996) found that initial trust in an employer moderates the relationship between a psychological contract violation and subsequent trust in the employer. Specifically, an employee with high initial trust will tend to think the violation is unintentional, just a misunderstanding. Simons and Peterson (2000) found that trust moderates the relationship between task conflict and relationship conflict within groups. They argued that, for employees with low trust, task conflict within a group is interpreted negatively by employees and subsequently results in relationship conflict. In contrary, for employees with high trust, task conflict would be more likely to be interpreted positively and hence would not be translates into relationship conflict. Bal, de Lange, Ybema, Jansen, and van der Velde (2011) stated that the relation of employees' perception of procedural justice with their turnover is buffered by high trust in employer. In the other words, the relationship of procedural justice and turnover is weaker for employees with high trust than with low trust. Specifically, although employees may perceive that the employer treats them unfairly, they do not leave their organization when they have a high trust-based relationship with their employer.

Given the limited foci commitment research about the moderating effect of trust on the relationship between justice and foci commitment, our theory-driven hypothesis could not be very rigorous. This study contributes to further theory development by reporting empirical relationships under the moderation of trust. Thus, this study proposes a rough hypothesis as below.

Hypothesis: Trust in supervisor has a moderating effect on the relationship between justice and commitment, with the weaker relationship for those with high trust in supervisor.

\section{Research Method}

\subsection{Sample}

The subjects of this study were teachers of public universities in Taiwan. Totally 2000 copies of questionnaires were mailed, and received 450 valid ones; the valid return rate was $22.5 \%$.

Sample composition: Gender- 41.5\% female, 58.5\% male; Age- 3.8\% under 30 years old, $22.4 \% 30-40$ years, $40.9 \% 40-50$ years, $32.9 \%$ over 50 years old; Service years, $18.0 \%$ under 5 years, $27.3 \% 5-10$ years, $29.6 \% 10-20$ years, $25.1 \%$ over 20 years; School size, $20.2 \%$ under 4,000 students, $23.1 \% 4,000-8,000$ students, $24.7 \%$ 8,000-15,000 students, $32.0 \%$ over 15,000 students.

\subsection{Measures}

This study measured justice and trust using a Likert scale format, and commitment using a 
semantic differential format. The measurements of all constructs were six-points. The score of each construct was an average of all items of the construct. Higher score stood for greater justice, trust, or commitment. Further, these construct scores were used in subsequent hypothesis testing.

\subsubsection{Justice}

Justice construct consisted of distributive justice, procedural justice, and interactional justice. The items were from Niehoff and Moorman (1993), Mo (2002), and Huang (2002). Distributive justice concerned the fairness of unit resource and teachers' loading distribution. Procedural justice referred to the supervisor's fairness of decision making in the processes and procedures. Interactional justice referred to the extent that the supervisor communicated with teachers and respected teachers. Distributive justice was measured by four items, whereas procedural and interactional justices involved five items.

\subsubsection{Trust}

Trust in this study referred to the teachers' perceptions of the supervisor's benevolence and integrity. The trust scale was based on the scale of followers' trust in leader developed by Podsakoff, MacKenzie, Moorman, and Fetter (1990). It included five items.

\subsubsection{Commitment}

Commitment comprised commitment to school, commitment to supervisor, and commitment to colleagues. Commitment to school meant teachers' psychological identification with school's objectives and values. Commitment to supervisor meant teachers' respect to their supervisor. Commitment to colleagues meant teachers' willingness to cooperate with their colleagues. This study adopted the view of multiple foci of Gregersen (1993) and Becker and Billings (1993) to design the measured items of commitment. We used four, four, and five items, respectively, to measure thee commitment dimensions (school, supervisor, and colleagues).

\subsection{Measurement Reliability}

For Cronbach's $\alpha$, distributive, procedural, and interactional justice were $0.81,0.84$, and 0.88 , respectively; trust was 0.87 ; commitment to school, commitment to supervisor, and commitment to colleagues were $0.85,0.90$, and 0.83 , respectively.

\subsection{Measurement Validity}

First, we used confirmatory factor analysis (CFA) to assess convergent validity together for all latent variables of distributive justice, procedural justice, interactional justice, trust, commitment to school, commitment to supervisor, and commitment to colleagues which were totally measured by 32 items. This tested model constrained each item to load only on one factor. Overall, results of this analysis indicated that the seven-factor structure was good fit to the data $\left(\chi^{2} / \mathrm{df}=2.52\right.$, goodness-of-fit index $[\mathrm{GFI}]=0.92$, confirmed fit index $[\mathrm{CFI}]=0.98$, and root mean square residual $[\mathrm{RMR}]=0.04)$. Second, regarding discriminant validity, all latent variables met pairwise chi-square difference test (Bagozzi, Yi, and Phillips, 1991), in 
which each pair of latent variables was analyzed by comparing the chi-square statistics of two models. One model was an unconstrained model (correlation between the two latent variables was free to estimate) and the other was a constrained model (correlation between the two latent variables was set to one). The results of chi-square difference test showed that, for each pair of latent variables, chi-square statistics were significantly lower for an unconstrained model than a constrained model. Thus, all latent variables had good discriminant validity.

\subsection{Common Method Variance (CMV)}

This study relied on self-reported questionnaire data suggesting possible mono-method bias and percept-percept inflated measures (Crampton and Wagner, 1994; Donaldson and Grant-Vallone, 2002). However, self-reporting did not necessarily inflate relationships between variables (Bruk-Lee and Spector, 2006). To mitigate mono-method bias, this study used several procedural remedies of Podsakoff, MacKenzie, Lee, and Podsakoff (2003). The measures of this study used different scale formats including Likert scale format and semantic differential format. We carefully constructed all survey items, and used pre-testing to eliminate item ambiguity (e.g., avoid double-barreled questions, avoid complicated syntax, keep questions simple, specific, and concise). The scale items were ordered randomly in the survey. Finally, this study used two unrelated jokes to create a psychological separation for each page's items.

Harman's one-factor (or single-factor) test is one of the most widely used techniques to address the issue of mono-method variance (Podsakoff et al., 2003). Following the test's instruction, all measured items in the study were together subjected to an exploratory factor analysis, and consequently, yielded five distinct factors and a general factor did not account for the majority of the covariance among measures (only 28.46\%). The results indicated that mono-method bias was not a serious threat.

\section{Research Results}

This study used hierarchical moderator regression analysis to test the moderating effects of trust on the relationship between justice and commitment. Specifically, we ran separate hierarchical moderator regression analysis for all three outcomes, commitment to school, commitment to supervisor, and commitment to colleagues. In step 1, distributive justice, procedural justice, interactional justice and trust were entered. In step 2, three cross-product terms used to capture the moderating effects were entered to test for the hypothesized moderating effect.

Prior to the analysis, to avoid multicollineaity between the main effect and two-way interaction terms, following the suggestions of Aiken and West (1991), Cronbach (1987), and Yi (1989), distributive justice, procedural justice, interactional justice and trust were mean-centered. After the data were mean-centered, the VIFs of all our regression models were less than 3, meeting the criterion of VIF lower than 10 that Hair, Anderson, Tatham, and Black (1998) suggested. Thus, in this study, multicollinearity of all regression models was not significant. 
Determining the moderating effects, most studies used the significance of interaction term as a basis (Baron and Kenny, 1986). Accordingly, regression coefficient of the interaction items of justice and trust were used to judge the moderating effects of this study. The results are shown in Table 1.

Table 1: Hierarchical Moderator Regression Analysis

\begin{tabular}{|c|c|c|c|c|c|c|}
\hline Variables & $\begin{array}{c}\text { Model } 1 \\
\text { Commitment } \\
\text { to school }\end{array}$ & $\begin{array}{c}\text { Model } 2 \\
\text { Commitment } \\
\text { to school }\end{array}$ & $\begin{array}{l}\text { Model } 3 \\
\text { Commitment } \\
\text { to supervisor }\end{array}$ & $\begin{array}{l}\text { Model } 4 \\
\text { Commitment } \\
\text { to supervisor }\end{array}$ & $\begin{array}{l}\text { Model } 5 \\
\text { Commitment } \\
\text { to colleagues }\end{array}$ & $\begin{array}{c}\text { Model } 6 \\
\text { Commitment } \\
\text { to colleagues }\end{array}$ \\
\hline Distributive justice & $0.17 * *$ & $0.16^{* *}$ & $0.27 * * *$ & $0.24 * * *$ & $0.29 * * *$ & $0.28 * * *$ \\
\hline Procedural justice & $0.24 * * *$ & $0.22 * * *$ & $0.35 * * *$ & $0.30 * * *$ & $0.12^{*}$ & $0.10^{*}$ \\
\hline Interactional justice & $0.29 * * *$ & $0.28 * * *$ & $0.39 * * *$ & $0.33 * * *$ & $0.27 * * *$ & $0.24 * * *$ \\
\hline Trust & $0.38 * * *$ & $0.33 * * *$ & $0.51 * * *$ & $0.46^{* * *}$ & $0.31 * * *$ & $0.30 * * *$ \\
\hline Distributive justice $\times$ trust & & -0.03 & & $-0.14 * *$ & & $-0.20 * *$ \\
\hline Procedural justice $\times$ trust & & -0.05 & & $-0.10^{*}$ & & -0.05 \\
\hline Interactional justice $\times$ trust & & -0.05 & & $-0.20 * * *$ & & -0.04 \\
\hline $\mathrm{R}^{2}$ & 0.37 & 0.38 & 0.45 & 0.54 & 0.31 & 0.36 \\
\hline $\mathrm{F}$ & $29.86^{* * *}$ & $30.40 * * *$ & $38.68 * * *$ & $49.91 * * *$ & $23.01 * * *$ & $28.16^{* * *}$ \\
\hline$\Delta \mathrm{R}^{2}$ & & 0.01 & & 0.09 & & 0.05 \\
\hline$\Delta \mathrm{F}$ & & 1.28 & & $12.65 * * *$ & & $9.12 * * *$ \\
\hline
\end{tabular}

Note:

(1) All regression coefficients are standardized.

(2) $* \mathrm{p}<0.05 ; * * \mathrm{p}<0.01 ; * * * \mathrm{p}<0.001$

\subsection{Moderating Effect of Trust on the Relationship between Justice and Commitment to School}

First, regarding commitment to school as a dependent variable, the results are shown in model 1 and model 2. The direct effects of three types of justice and trust (model 1 ) accounted for $37 \%$ of the variance in commitment to school. The addition of the interaction terms of three types of justice and trust (model 2) did not add significant variance explained in commitment to school above and beyond the main effects (change $\mathrm{F}=1.28$, n.s.). Moreover, all the coefficients of interaction terms of three types of justice and trust were negative but nonsignificant. Hence, trust could not moderate the relationship between three types of justice and commitment to school. In other words, when the dependent variable is commitment to school, the hypothesis is not supported.

\subsection{Moderating Effect of Trust on the Relationship between Justice and Commitment to Supervisor}

Second, regarding commitment to supervisor as a dependent variable, the results are shown in model 3 and model 4 . The direct effects of three types of justice and trust (model 3) accounted for $45 \%$ of the variance in commitment to supervisor. The addition of the interaction terms of three types of justice and trust (model 4) accounted for a significant increment in variance $\left(\Delta \mathrm{R}^{2}=9 \%, \mathrm{p}<0.001\right)$ on commitment to supervisor. In addition, as hypothesized, all beta weights of the interaction terms were negative for distributive justice $(\beta=-0.14, p<0.01)$, 
procedural justice $(\beta=-0.10, p<0.05)$, and interactional justice $(\beta=-0.20, p<0.001)$, indicating that trust in supervisor attenuates the effects of three types of justice on commitment to supervisor. Hence, when the dependent variable is commitment to supervisor, the hypothesis is supported.

\subsection{Moderating Effects of Trust on the Relationship between Justice and Commitment to Colleagues}

Third, regarding commitment to colleagues as a dependent variable, the results are shown in model 5 and model 6 . The direct effects of three types of justice and trust (model 5) accounted for $31 \%$ of the variance in commitment to colleagues. The addition of the interaction terms of three types of justice and trust (model 6) accounted for a significant increment in variance $\left(\Delta \mathrm{R}^{2}=5 \%, \mathrm{p}<0.001\right)$ on commitment to colleagues. In addition, as hypothesized, all beta weights of the interaction terms were negative. However, only the interaction term of distributive justice and trust was significant $(\beta=-0.20, p<0.01)$, but in the respect of procedural justice $(\beta=-0.05$, n.s.) and interactional justice $(\beta=-0.04$, n.s. $)$, there were not significant, indicating that trust in supervisor only attenuates the effects of distributive justice on commitment to colleagues. Hence, when the dependent variable is commitment to colleagues, the hypothesis is partially supported.

\section{Conclusions and Suggestions}

\subsection{Conclusions}

Most past research regarded commitment as an organizational commitment. In addition, some research proposed that trust weakens the effect of a partner's action on truster's response (Dirks and Ferrin, 2001) or the effect of procedural justice on turnover (Bal et al., 2011). This study explored that trust in supervisor moderates the effect of three types of justice on three types of commitment. Based on the findings of this study, teachers of public universities do not completely support the weakening effect of trust. Although all interaction terms of justice and trust are negative, some are not significant. So, whether trust has the weakening effect for the influence of justice on commitment must depend on the type of justice and commitment. This is the most contribution of this study. Specifically, foci commitment is needed to further explore because it can bring us specific findings. We find that trust in supervisor has fully no ability to moderate the effect of three types of justice on commitment to school. Surprisingly, trust can moderate all relationships between three types of justice and commitment to supervisor. In addition, the result of commitment to colleagues exactly lies in above two cases. Trust in supervisor can only moderate the effect of distributive justice on commitment to colleagues, but the effects of the other two justices on commitment to colleagues are not moderated by trust in supervisor.

\subsection{Suggestions}

The measurement tool of this study has good reliability and validity, and the validation of hypotheses is according to proper test procedures. However, this study still has some 
limitations, and needs the efforts of future research.

Firstly, this study only samples teachers of public universities in Taiwan. The generalization of the research findings needs further research. To extend applicability (Churchill, 1979), future research can expand the sampling scope to elementary schools, junior high schools, and senior high schools, or so much as private schools.

To avoid too high complexity of research, this study focuses trust on supervisors and defines it as the benevolence and integrity of the supervisors. However, like commitment, trust's target should be considered. Thence, foci trust is suggested to further research, such as trust in school and trust in colleagues.

In managerial practice, a supervisor must strength teachers' trust in him/her. When teachers trust in their supervisor, justice becomes relatively unimportant for them in some cases, indicating teachers would take a generous and open-minded attitude to supervisor's leadership.

\section{Acknowledgement}

The author is grateful to National Science Council in Taiwan for the financial support (NSC 99-2410-H-024-009).

\section{References}

Adams, J. S. (1965). Inequity in social exchange. In Berkowitz. (Ed.), Advances in experimental psychology (Vol.2, pp.267-299). San Diego, CA: Academic Press.

Aiken, L. S., \& West, S. G. (1991). Multiple regression: Testing and interpreting interactions. Newbury Park, CA: Sage.

Bagozzi, R. P., Yi, Y., \& Phillips, L. W. (1991). Assessing construct validity in organizational research. Administrative Science Quarterly, 36(3), 421-458. http://dx.doi.org/10.2307/2393203

Bal, P. M., de Lange, A. H., Ybema, J. F., Jansen, P. G. W., \& van der Velde, M. E. G. (2011). Age and trust as moderators in the relation between procedural justice and turnover: A large-scale longitudinal study. Applied Psychology, 60(1), 66-86. http://dx.doi.org/10.1111/j.1464-0597.2010.00427.x

Baron, R. M., \& Kenny, D. A. (1986). The moderator-mediator variable distinction in social psychological research: Conceptual, strategic, and statistical considerations. Journal of $\begin{array}{llll}\text { Personality and Social Pschology, } & \text { 51(6), }\end{array}$ http://dx.doi.org/10.1037/0022-3514.51.6.1173

Becker, T. E. (1992). Foci and bases of commitment: Are they distinctions worth making? Academy of Management Journal, 35(1), 232-244. http://dx.doi.org/10.2307/256481

Becker, T. E., \& Billings, R. S. (1993). Profiles of commitment: An empirical test. Journal of 
Organizational Behavior, 14(2), 177-190. http://dx.doi.org/10.1002/job.4030140207

Becker, T. E., Billings, R. S., Eveleth, D. M., \& Gilbert, N. L. (1996). Foci and bases of employee commitment: Implications for job performance. Academy of Management Journal, 39(2), 464-482. http://dx.doi.org/10.2307/256788

Becker, T. E., \& Kernan, M. C. (2003). Matching commitment to supervisors and organizations to in-role and extra-role performance. Human Performance, 16(4), 327-348. http://dx.doi.org/10.1207/S15327043HUP1604_1

Bentein, K., Stinglhamber, F., \& Vandenberghe, C. (2002). Organization-, supervisor-, and workgroup-directed commitments and citizenship behaviours: A comparison of models. European Journal of Work and Organizational Psychology, 11(3), 341-362. http://dx.doi.org/10.1080/13594320244000201

Bies, R. J., \& Moag, J. S. (1986). Interactional justice: Communication criteria for fairness. In B. Sheppard (Ed.), Research in organizational behavior (Vol.9, pp.289-319). Greenwich, CT: JAI Press.

Blau, P. (1964). Exchange and power in social life. New York: Wiley.

Bruk-Lee, V., \& Spector, P. E. (2006). The social stressors-counterproductive work behaviors link: Are conflicts with supervisors and coworkers the same? Journal of Occupational Health Psychology, 11(2), 145-156. http://dx.doi.org/10.1037/1076-8998.11.2.145

Churchill, G. A. (1979). A paradigm for developing better measures of marketing constructs. Journal of Marketing Research, 16(1), 64-73. http://dx.doi.org/10.2307/3150876

Clugston, M., Howell, J. P., \& Dorfman, P. W. (2000). Does cultural socialization predict multiple bases and foci of commitment? Journal of Management, 26(1), 5-30. http://dx.doi.org/10.1177/014920630002600106

Cohen, A. (2003). Multiple commitments in the workplace: An integrative approach. New York: Lawrence.

Crampton, S. M., \& Wagner, J. A. (1994). Percept-percept inflation in micro-organizational research: An investigation of prevalence and effect. Journal of Applied Psychology, 79(1), 67-76. http://dx.doi.org/10.1037/0021-9010.79.1.67

Cronbach, L. J. (1987). Statistical tests for moderator variables: Flaws in analysis recently proposed. Psychological Bulletin, 102(3), 414-417. http://dx.doi.org/10.1037//0033-2909.102.3.414

Dirks, K. T., \& Ferrin, D. L. (2001). The role of trust in organizational settings. Organizational Science, 12(4), 450-467. http://dx.doi.org/10.1287/orsc.12.4.450.10640

Donaldson, S. I., \& Grant-Vallone, E. J. (2002). Understanding self-report bias in organizational behavior research. Journal of Business and Psychology, 17(2), 245-260. http://dx.doi.org/10.1023/A:1019637632584 
Folger, R., \& Greenberg, J. (1985). Procedural justice: An interpretative analysis of personnel systems. In K. Rowland \& G. Ferris (Eds.), Research in personnel and human resources management (Vol.3, pp.141-183). Greenwich, CT: JAI Press.

Gregersen, B. (1993). Multiple commitments at work and extrarole behavior during three stages of organizational tenure. Journal of Business Research, 26(1), 31-47. http://dx.doi.org/10.1016/0148-2963(93)90041-M

Hair, J. F. Jr., Anderson, R. E., Tatham, R. L., \& Black, W. C. (1998). Multivariate data analysis. New York: Macmillan.

Hartog, D. N. D., \& Belschak, F. D. (2007). Personal initiative, commitment and affect at work. Journal of Occupational and Organizational Psychology, 80(4), 601-622. http://dx.doi.org/10.1348/096317906X171442

Huang, J.-C. (2002). Organizational justice and organizational citizenship behavior: The mediating effect of cognition- and affect-based trust. NTU Management Review, 12(2), 107-141.

Iverson, R. D., \& Roy, P. (1994). A causal model of behavioral commitment: Evidence from a study of Australian blue-collar employees. Journal of Management, 20(1), 15-41. http://dx.doi.org/10.1177/014920639402000102

Jiang, D.-Y., \& Cheng, B.-S. (2003). Studies on organizational loyalty, commitment, and citizenship behavior in Taiwan: A critical review. Research in Applied Psychology, 19, 175-209.

Magner, N., \& Welker, R. B. (1994). Responsibility center managers' reactions to justice in budgetary resource allocation. Advances in Management Accounting, 3, 237-253.

McDonald, G. W. (1981). Structural exchange and marital interaction. Journal of Marriage and the Family, 43(4), 825-839. http://dx.doi.org/10.2307/351340

Mo, C.-F. (2002). A study of the effect of organizational justice and organizational trust on organizational commitment of junior high school physical education teachers. Unpublished doctoral dissertation, National Taiwan Normal University, Taipei, Taiwan.

Niehoff, B. P., \& Moorman, R. H. (1993). Justice as a mediator of the relationship between methods of monitoring and organizational citizenship behavior. Academy of Management Journal, 36(3), 527-556. http://dx.doi.org/10.2307/256591

Novelli, L., Kirkman, B. L., \& Shapiro, D. L. (1995). Effective implementation of organizational change: An organizational justice perspective. In C. L. Cooper \& D. M. Rousseau (Eds.), Trends in organizational behavior (Vol.2, pp.15-36), New York: John Wiley.

Nowakowski, J. M., \& Conlon, D. E. (2005). Organizational justice: Looking back, looking forward. International Journal of Conflict Management, 16(1), 4-29. http://dx.doi.org/10.1108/eb022921 
O'Reilly, C. A., \& Chatman, J. A. (1986). Organizational commitment and psychological attachment: The effects of compliance, identification, and internalization on prosocial behavior. Journal of Applied Psychology, 71(3), 492-499. http://dx.doi.org/10.1037//0021-9010.71.3.492

Podsakoff, P. M., MacKenzie, S. B., Lee, J.-Y., \& Podsakoff, N. P. (2003). Common method biases in behavioral research: A critical review of the literature and recommended remedies. Journal of Applied Psychology, 88(5), 879-903. http://dx.doi.org/10.1037/0021-9010.88.5.879

Podsakoff, P. M., MacKenzie, S. B., Moorman, R. H., \& Fetter, R. (1990). Transformational leader behaviors and their effects on followers' trust in leader, satisfaction, and organizational citizenship behaviors. Leadership Quarterly, 1(2), 107-142. http://dx.doi.org/10.1016/1048-9843(90)90009-7

Razak, N. A., Darmawan, I. G. N., \& Keeves, J. P. (2010). The influence of culture on teacher commitment. Social Psychology of Education, 13(2), 185-205. http://dx.doi.org/10.1007/s11218-009-9109-z

Redman, T., \& Snape, E. (2005). Unpacking commitment: multiple loyalties and employee behaviour. Journal of Management Studies 42(2), 301-328. http://dx.doi.org/10.1111/j.1467-6486.2005.00498.x

Reichers, A. E. (1985). A review and reconceptualization of organizational commitment. The Academy of Management Review, 10(3), 465-476. http://dx.doi.org/10.2307/258128

Robinson, S. L. (1996). Trust and breach of the psychological contract. Administrative Science Quarterly, 41(4), 574-599. http://dx.doi.org/10.2307/2393868

Rousseau, D. M., Sitkin, S. B., Burt, R. S., \& Camerer, C. (1998). Not so different after all: A cross-discipline view of trust. The Academy of Management Review, 23(3), 393-404. http://dx.doi.org/10.5465/AMR.1998.926617

Shockley-Zalabak, P., Ellis, K., \& Winograd, G. (2000). Organizational trust: What it means, why it matters. Organization Development Journal, 18(4), 35-48.

Simons, T., \& Peterson, R. (2000). Task conflict and relationship conflict in top management teams: The pivotal role of intragroup trust. Journal of Applied Psychology, 85(1), 102-111. http://dx.doi.org/10.1037//0021-9010.85.1.102

Singh, K., \& Billingsley, B. S. (1998). Professional support and its effects on teachers' commitment. Journal of Educational Research, 91(4), 229-239. http://dx.doi.org/10.1080/00220679809597548

Tan, H. H., \& Tan, C. S. F. (2000). Toward the differentiation of trust in supervisor and trust in organization. Genetic, Social, and General Psychology Monographs, 126(2), 241-260.

Tsui, K. T., \& Cheng, Y. C. (1999). School organizational health and teacher commitment: A contingency study with multi-level analysis. Educational Research and Evaluation, 5(3), 
249-268. http://dx.doi.org/10.1076/edre.5.3.249.3883

Van den Bos, K., Wilke, H. A. M., \& Lind, E. A. (1998). When do we need procedural fairness? The role of trust in authority. Journal of Personality and Social Psychology, 75(6), 1449-1458. http://dx.doi.org/10.1037//0022-3514.75.6.1449

Vandenberghe, C., \& Bentein, K. (2009). A closer look at the relationship between affective commitment to supervisors and organizations and turnover. Journal of Occupational and Organizational Psychology,

$82(2)$, 331-348. http://dx.doi.org/10.1348/096317908X312641

Veurink, S. A., \& Fischer, R. (2011). A refocus on foci: A multidimensional and multi-foci examination of commitment in work contexts. New Zealand Journal of Psychology, 40(3), 160-167.

Wasti, S. A., \& Onder, C. (2009). Commitment across cultures: Progress, pitfalls and propositions. In H. J. Klein, T. E. Becker \& J. P. Meyer (Eds.), Commitment in organizations: Accumulated wisdom and new directions (pp.309-343). New York: Routledge Taylor and Francis Group.

Yang, F. H., Wu, M., Chang, C. C., \& Chien, Y. (2011). Elucidating the relationships among transformational leadership, job satisfaction, commitment foci and commitment bases in the public sector. Public Personnel Management, 40(3), 265-278.

Yi, Y. (1989). On the evaluation of main effects in multiplicative regression models. Journal of the Market Research Society, 31(1), 134-138.

\section{Copyright Disclaimer}

Copyright reserved by the author(s).

This article is an open-access article distributed under the terms and conditions of the Creative Commons Attribution license (http://creativecommons.org/licenses/by/3.0/). 